\title{
On Deviating from Absolute Priority: The Case of Tort Claims and Active Creditors
}

\author{
Joshua 0. Anyangah \\ Faculty of Business, Athabasca University, Athabasca, Canada \\ Email: joshua.anyangah@ualberta.net, janyangah@athabascau.ca
}

How to cite this paper: Anyangah, J.O. (2017) On Deviating from Absolute Priority: The Case of Tort Claims and Active Creditors. Theoretical Economics Letters, 7, 471-489.

https://doi.org/10.4236/tel.2017.73036

Received: March 1, 2017

Accepted: April 11, 2017

Published: April 14, 2017

Copyright $\odot 2017$ by author and Scientific Research Publishing Inc. This work is licensed under the Creative Commons Attribution International License (CC BY 4.0).

http://creativecommons.org/licenses/by/4.0/

\section{(c) (i) Open Access}

\begin{abstract}
The impact of deviating from absolute priority rule, a basic tenet of bankruptcy law that accords secured creditors a privileged position in bankruptcy distribution, has long been at the centre of research on bankruptcy. This paper develops a model of a firm that can cause an accident and then claim bankruptcy to investigate the ex ante effects of elevating tort claims a head of creditors. In the model, the firm (or its manager) controls an unobservable care (or effort) decision. The creditor not only provides the requisite capital, but also exercises control over the firm by virtue of its significant cash flow rights. Together managerial care and creditor control determine the distribution of the tortious harm. We find that according tort claims a privileged position relative to creditors leads to a shift away from managerial care and towards more creditor control. As a consequence, subordinating secured creditor has an ambiguous effect on the expected social welfare.
\end{abstract}

\section{Keywords}

Absolute Priority Rule, Bankruptcy, Tort Claims

\section{Introduction}

Absolute priority rule (APR) is central to the structure of asset allocation and distribution process in bankruptcy proceedings in many countries ${ }^{1}$. More precisely, the rule determines the basic order according to which competing creditors are allocated a firm's assets in the event of bankruptcy. At its core is the idea that unsecured claims are entitled to bankruptcy distribution unless and until secured creditors are paid in full. The main argument in support of this principle is that priority of secured debt mitigates agency conflicts between borrowers and creditors and facilitates efficient loans that could not occur if secured credit were not awarded priority [1] [2]. This proposition is not incontrovertible, however. ${ }^{1}$ See, for example, Chapters 7 and 11 of the US Bankruptcy Code or the Receivership code in UK. 
The typical criticism is that granting full priority to secured creditors may actually hurt efficiency. Because conferring priority to secured creditors protects the payment of their debt in the event of bankruptcy, such creditors are essentially insulated from the full costs or the downside risk of bankruptcy. As a consequence, they have no incentive to correctly price credit or adequately monitor their borrowers' behaviour and risk-taking [3]. One way in which to remedy this undesirable effect is to violate APR by switching priorities and instead granting unsecured creditors privileged position over secured creditors.

Not surprisingly, a number of authors have attempted to examine how deviating from APR can distort various aspects of managerial decision making. Conspicuously absent from these studies has been any effort to investigate the implication of APR violation for tort deterrence. Mass tort actions have triggered so many prominent bankruptcy liquidations or reorganizations [3] that the dearth of a systematic analysis of the impact of APR deviation on tort deterrence is glaring. This paper examines APR violations in the context of tort deterrence. More precisely, we use the case of a firm that can cause tortious harm and then claim bankruptcy to investigate the ex ante effects of elevating tort claims a head of secured creditors. In particular, we seek to determine how subordinating secured credit in favour of tort claims will affect deterrence and expected social welfare. In the model, the firm generates stochastic harm, whose distribution is influenced by the level of managerial care and the control that the creditor exercises over the business, a function that we simply refer to as "creditor control." Thus, in the current model, creditors not only provide the requisite capital. They also actively participate in the affairs of the firm and in this way influence the firm's performance. The tort harm generated by the firm is in essence a composite variable that is influenced by the action of both the debtor and the creditor. There is a double-sided moral hazard problem in that the two actions, care and creditor control, are not observable and cannot therefore be contracted upon. We show that according tort claims a privileged position relative to secured creditors leads to a shift away from entrepreneurial care and towards more creditor control.

The logic behind this result can be presented along the following lines. First, in a bilateral moral hazard setting-characterized by a single incentive instrument such as ours-motivating one party necessarily implies diluting the incentives for the other. Second, in our model, elevating tort claims leads to an increase in the interest rate as creditors demand compensation for their increased exposure to tort risk. The higher interest rate makes creditor control more rewarding thereby lessening the severity of the creditor's moral hazard problem, which is a move in the right direction. However, the higher interest rate has a perverse effect in that it reduces the marginal return from care thereby worsening the entrepreneurial moral hazard. Technically, subordinating the secured creditor's status leads to a relaxation of the creditors incentive compatibility constraint, but a tightening of the entrepreneur's incentive compatibility condition. Since the tort damage is a composite variable that depends on the actions 
undertaken by both the debtor and the creditor, subordinating secured creditors has an ambiguous effect on expected social welfare.

Our article extends the literature on the effects of deviation from APR. This work, which essentially examines the implication of impairing prebankruptcy entitlements, has generally shown mixed results. Fisher, Martel and Gaviousc [4] model a situation in which firms in financial distress engage in claim substitution, a welfare-damaging practice where firms use funds owed to a tax authority to pay trade creditors before filing for reorganization. They show that granting priority to the tax authority is ex ante efficient in that it reduces the incentive for firms to engage in claims substitution. In Berkovitch, Israel, and Zender [5] [6] deviation from AP increases the entrepreneur's incentive to exert effort by protecting the sunk investment. Heinkel and Zechner [7], Kalay and Zender [8], and Berkovitch and Israel [9] [10] focus on the interaction between bankruptcy and the flow of information. They demonstrate that deviations from absolute priority rules improve the bankruptcy outcome as they facilitate the transfer of information between privately informed managers and their less informed creditors. Longhofer [11] shows that APR violations exacerbate credit rationing problems by reducing the payment lenders receive in default states.

While the foregoing studies appear to suggest that APR deviation is generally desirable, there are also contributions in which deviations from APR have perverse effects. APR deviations may encourage risk-taking by firms near bankruptcy [12] [13]; they may also aggravate managerial moral hazard priorto bankruptcy [14].

The model presented here is different from these in two respects: First, all these formal studies tend to focus on (a) the restructuring process of a firm in financial distress and (b) potential conflict among voluntary creditors (i.e., senior versus junior creditors) and how this conflict affects both ex ante and ex post incentives. In the current model, however, an insolvent firm is forced into outright liquidation-as opposed to reorganization. We also assume that the conflict that ensues occurs between voluntary creditors (i.e., secured creditors) and involuntary creditors (i.e., tort victims). The distinction is nontrivial: whereas voluntary creditors own contractual claims against the firm, involuntary creditors have not consented to their status. Furthermore, while contractual creditors possess the ability to bargain with their debtors ex ante, tort claimants are in no position to protect themselves ex ante; they become creditors by dint of the fact that the debtor committed the wrongful acts.

The second distinguishing feature relates to the role of creditors in the affairs of the firm. The extant literature tends to ascribe a more passive role to the creditor and thus ignores the potential contribution the creditor might make to the firm's outcome. In these studies, it is often presumed that the creditor plays no role beyond providing the requisite capital. In reality, of course, creditors do exert influence over important firm decisions. The principal way in which creditors receive such powers is when the firm violates loan covenants. More precisely, in the event of a covenant breach, the creditor may use the threat of ac- 
celerating outstanding debt to take any number of actions such as influencing the firm's investment policy, advising management "behind the scenes" or replacing top management (e.g., Nini et al. [15]; Shleifer and Vishny [16]; Baird and Rasmussen $[17])^{2}$. In essence, these covenants transform the creditor into a disciplining agent with significant influence over the firm's performance. In this paper, we present a more realistic picture of the debtor-creditor relationship by allowing for the creditor to interfere with the firm's decision making and performance. As a consequence, the distribution of the harm is dependent not on a single choice variable, but is actually a product of multiple decisions, namely managerial care and creditor control. This implies that the optimal contract must be structured to ensure that both parties have the incentives to behave properly. The present model highlights the basic idea that there must be a tradeoff between these two incentives and that APR deviations affect how this tradeoff is made.

Our idea of creditor control is reminiscent of the "special" role of financial intermediaries as delegated monitors (Diamond [18]). However, our view of the role of debt possesses a somewhat distinct flavour. At the core of the literature on monitored debt is the premise that creditor monitoring curtails the moral hazard problem. In Jensen [19], monitoring by the creditor mitigates the agency problem by reducing free cash flow and managerial discretion. In Diamond [20], Rajan [21], and Sharpe [22], the creditor acquires private information about the borrowing firm that enables the bank to monitor the firm and implement the correct investment choices. Besanko [23] presents a model in which creditor monitoring allows the creditor to observe managerial effort and to force the manager to improve their effort. In the current model, by contrast, the creditor's intervention is not aimed at reducing the severity of managerial moral hazard. Rather, it allows the creditor to have a direct influence over the firm's performance-much in the same way that shareholders or board of directors control managerial discretion.

Similar to our paper, Banerji et al. [24], in an entirely different context, allows for the creditor to directly wield power over the borrowing firm. However, our paper differs from theirs with regards to the source of these control rights. In Banerji et al [24], the creditor is able to interfere in the affairs of the firm by virtue of her equity stake in the borrowing firm. In contrast, our paper abstracts from any equity participation by the creditor. Instead, it presumes that the creditor's powers originate from the significant cash flow rights that she commands. Thus, our paper captures the general idea that a creditor need not acquire an equity stake in their borrower firm in order to wield the levers of power. A debt contract, in and of itself, can accord the creditor control rights that rival those of equity holders [17].

The remainder of this paper is organized as follows. Section 2 develops the central elements of the model. Section 3 presents the benchmark solutions. Section 5 presents the borrower's solution under limited information. Section 5

${ }^{2}$ According to Baird and Rasmussen [17], these covenants may give creditors so much control as to blur the line between debt and equity. 
discusses the key results and then concludes.

\section{The Model}

A firm does not have any capital of its own but has access to a business investment idea or project that requires some fixed initial investment of $\$ 1^{3}$. Thus, in order for the firm to undertake its project, it must obtain the required capital from an outside party, whom we simply refer to as the creditor.

Creditors, who are also risk neutral, operate in a competitive credit market and have access to an unlimited supply of capital at a constant gross rate of interest $\rho$, which we assume is also society's opportunity cost of funds. We take it that the entrepreneur can obtain funding from at most one creditor, but the creditor can fund several projects. We also stipulate that the creditor can enter into a separate contract with each borrower and that each contract is designed independently of the other.

A significant economic assumption of the model relates to the role of the creditor in the affairs of the firm. The standard approach in the literature has been to assume that only the manager (or entrepreneur) can influence the firm's outcome; that is, that creditors do not play an active role in the affairs of the firm. We abandon this assumption here and instead stipulates that the creditor exercises direct and significant control over the firm and in this way influences the firm's performance (e.g., Nini et al. [15]; Baird and Rasmussen [17]). Throughout, we refer to the creditor's intervention in the affairs of the firm as creditor control ${ }^{4}$. More precisely, we assume that the creditor commits resources at time 0 to exercise control over the firm. The monetary costs of this function are represented by $a$. We can think of the creditor as a bank. Thus our focus on a bank exploits its ability to wield power over its borrower's decision making.

An investment of size $\$ 1$ results a net cash flow $1+v$, where $v \in(0, l)$ is the rate of return on investment. We assume that $v$ is costlessly verifiable. Each started project also carries the risk of causing an accident and inflicting harm, whose monetary value is denoted by $F$. $l$ itself is a stochastic variable with support over the interval $[0, L]$. The probability distribution of $l$ is a function of two variables: $e$, the level of care or effort or care expended by the firm (or entrepreneur) and the level of control exercised by the creditor, a. The monetary equivalent disutility of care is represented by $e$. Denote by $F(l \mid e, a)$ the cumulative distribution function of $I$ given the level of care $e$ and control $a$ by the creditor respectively. We make the following assumptions with respect to the distribution of $l$ :

Assumption 1. For all fixed $l \in[0, L], F(l \mid .,$.$) is differentiable over \mathbb{R}_{++}^{2}$;

${ }^{3}$ Throughout we use the terms "firm," "borrower," "entrepreneur" and "manager" interchangeably. ${ }^{4}$ Note that our idea of creditor intervention differs somewhat from the idea of financial intermediaries as delegated monitors (e.g. Diamond [18]), where creditor intervention is presumed to curtail the moral hazard problem.

${ }^{5}$ The harm can be understood as (a) a hazard associated with the consumption of a product or (b) environmental, health and safety risk associated with production. The victim could be thought of as an individual (or individuals) who directly suffers the harm or an environmental agency that performs the clean-up after the fact. 
Assumption 2. For all fixed $l \in[0, L], \frac{\partial}{\partial l}\left[\frac{f_{e}(l \mid e, a)}{f(l \mid e, a)}\right]$ and $\frac{\partial}{\partial l}\left[\frac{f_{a}(l \mid e, a)}{f(l \mid e, a)}\right]$;

Assumption 3. $F_{e a}(l \mid e, a)=F_{a e}(l \mid e, a)=0 \forall(l, e, a)$;

Assumption 4. For all fixed $l \in[0, L], F(l \mid .$.$) is concave over \mathbb{R}_{++}^{2}$.

Assumption 1 simply says that $F(l \mid .,$.$) is twice continuously differentiable$ with respect to all arguments. This is necessary for the existence of an optimal solution. Assumption 2 is the Monotone Likelihood Ratio Property (MLRP). It indicates that higher values of $(e, a)$ result in lower levels of social harm in the sense of first order stochastic dominance. That is, for a higher level of $e$ or $a$, the probability that social harm is less than any given value (weakly) increases. The MLRP can also be stated as $F_{e}(l \mid .,) \geq 0,. \forall(l, e, a) F_{a}(l \mid .,) \geq 0,. \forall(l, e, a)$. Assumption 3 indicates the absence of complementarity between the two inputs and is made for analytical simplicity. Assumption 4 is necessary to guarantee the uniqueness of the creditor and the manager's effort choices. Following standard practice, we note that $F_{e}(0 \mid e, a)=F_{e}(L \mid e, a)=F_{a}(0 \mid e, a)=F_{a}(L \mid e, a)=0$ for any action $(a, e)$.

A contract requires the creditor to provide the sum of $\$ 1$ as a loan. In return, its specifies that the firm will pay the creditor $(1+R)$ if the firm is solvent; in the event of bankruptcy, ownership of the firm and its assets are transferred to the creditor. In essence, the creditor's loan to the firm is secured by the firm's cash flow.

For a given return $(1+v)$ and debt obligation $(1+R)$, there is a critical amount of harm $l^{*}$ at which the firm is just able to meet its legal obligations. That is,

$$
(1+v)-(1+R)-l^{*}=0 .
$$

Equation (1) defines the solvency condition, which occurs when $l=l^{*}$. Clearly, this equation defines $l^{*}$ as a function of $R$ :

$$
l^{*}=l^{*}(R) .
$$

Thus, $l^{*}$ is the threshold such that if $l \leq l^{*}$, the firm can meet all its obligation. On the other hand, if $l>l^{*}$, the firm cannot meet its payment obligations. In that event, it files for bankruptcy. Bankruptcy proceedings result in the seizure and the distribution of the firm's assets amongst its claimants according to the priority rule in place. Thus, we rule out reorganization. The probability that the firm is solvent is Prob $\left(l \leq l^{*}=\int_{0}^{l^{*}} f(l \mid e, a) \mathrm{d} l=F\left(l^{*} \mid e, a\right)\right)$. We assume that bankruptcy results in the diminution of the firm's assets such that the firm's liquidation value is only $(1+z)$, where $z<v$.

\section{Benchmark Solutions}

Before proceeding to characterize the borrower's problem under bilateral moral hazard, we record two useful benchmarks. The first benchmark is the social planner's problem, which is to maximise social welfare under the assumption that both $e$ and $a$ are observed publicly (i.e., there is no moral problem). The 
second benchmark considers the borrower's problem under full information.

\subsection{The Social Optimum}

The social objective is to choose the level of care and creditor control that maximizes the expected social welfare. Social welfare $W$ equals the firm's net cash flows in both states of the world, $(1+v)$ and $(1+z)$, respectively, less the cost of taking care $e$, the cost of creditor controla, the expected environmental harm I, and society's opportunity cost of financing the firm's investment:

$$
W(e, a)=\int_{0}^{l^{*}}\{(1+v)-l\} f(l \mid e, a) \mathrm{d} l+\int_{l^{*}}^{L}\{(1+z)-l\} f(l \mid e, a) \mathrm{d} l-e-a-\rho .
$$

Integrating the social welfare function by parts and simplifying yields

$$
W(.)=F\left(l^{*} \mid e, a\right)[v-z]-\int_{0}^{L} I f(l \mid e, a) \mathrm{d} l-e-a-\rho .
$$

The social optimum is defined by $e$ and $a$ that maximizes social welfare:

$$
\max _{a, e} W(e, a) \text {. }
$$

Assuming an interior solution to the social planner's problem, the optimal level of care, $e^{*}$, and the optimal level of creditor control, $a^{*}$, satisfy

$$
\begin{aligned}
& W_{e}(.)=F_{e}\left(l^{*} \mid e, a\right)[v-z]+\int_{0}^{L} F_{e}(l \mid e, a) \mathrm{d} l-1=0 \\
& W_{a}(.)=F_{a}\left(l^{*} \mid e, a\right)[v-z]+\int_{0}^{L} F_{a}(l \mid e, a) \mathrm{d} l-1=0
\end{aligned}
$$

The concavity of $F(l \mid e, a)$ ensures that this solution is unique. This solution has an easy interpretation. (4) says that the level of care should be increased until the marginal disutility of increased care equals the marginal social benefit of increased care. Marginal social benefits comprise the incremental benefit from avoiding bankruptcy and reduced accidents costs. Equation (5) can be similarly interpreted.

\subsection{The Firm's Problem under Full Information}

The firm's problem differs from the social planner's problem in two respects: First, whereas the social planner evaluates accident costs in all states of the world, the firm evaluates accident costs only in those states of the world in which it is solvent. Second, in order for the firm to undertake its project, it must secure external financing from a competitive capital market. In return to providing the requisite funds, the financial contract between the firm and the creditor requires that the firm make a repayment of $(1+R)$. This repayment amount must be structured to ensure that the creditor earns zero economic profit.

Our approach is to first examine an initial setting where the creditor is accorded full priority in bankruptcy proceedings. We then investigate the effects of violating the secured creditor status of the creditor by characterizing the optimal contract when tort claims are elevated ahead of the creditor.

\subsubsection{Creditor Priority (APR)}

Suppose that the bankruptcy law entitles the creditor, by virtue of their secured 
status, to be paid in full before tort victims and other unsecured claimants receive any payment. The entrepreneur's expected payoff can be written as

$$
u=\int_{0}^{l^{*}}\{(1+v)-(1+R)-l\} f(l \mid e, a) \mathrm{d} l-e .
$$

Equation (6) shows that with probability $F\left(I^{*} \mid e, a\right)$, the firm is solvent, in which case the firm receives the residual $(1+v)-(1+R)-l$ [after paying $(1+R)$ to the lender and compensating the victim]. However, with probability $\left[1-F\left(l^{*} \mid e, a\right)\right]$, the firm files for bankruptcy and is liquidated. In that event, the borrower gets nothing. The last term is the cost of undertaking care.

The creditor's expected payoff can be written as follows:

$$
\begin{aligned}
\pi & =\int_{0}^{l^{*}}(1+R) f(l \mid e, a) \mathrm{d} l+\int_{l^{*}}^{L}(1+z) f(l \mid e, a) \mathrm{d} l-a-\rho \\
& =F\left(l^{*} \mid e, a\right)(1+R)+\left[1-F\left(l^{*} \mid e, a\right)\right][1+z]-a-\rho .
\end{aligned}
$$

Equation (7) shows that with probability $F\left(I^{*} \mid e, a\right)$, the firm is solvent, in which case the creditor receives $(1+R)$. However, with probability $\left[1-F\left(l^{*} \mid e, a\right)\right]$, the firm files for bankruptcy and is liquidated. In that event, the creditor, because she is accorded full priority, expropriates all of the firm's recoverable assets, while the borrower gets nothing.

The program of the borrower can be written as

$$
\max _{a, e, R} u=\int_{0}^{l^{*}}\{(1+v)-(1+R)-l\} f(l \mid e, a) \mathrm{d} l-e
$$

subject to

$$
F\left(l^{*} \mid e, a\right)(1+R)+\left[1-F\left(l^{*} \mid e, a\right)\right][1+z]-a-\rho=0 .
$$

Equation (9) is the zero economic-profit condition. We can simplify the objective function. Substituting for $(1+R)$ in the objective function using (9), the unconstrained optimization problem becomes

$$
\max _{a, e} u=F\left(l^{*} \mid e, a\right)(1+v)+\left[1-F\left(l^{*} \mid e, a\right)\right][1+z]-\int_{0}^{l^{*}} I f(l \mid e, a) \mathrm{d} l-e-a-\rho .
$$

The optimal ex ante level of care $e$ and the optimal level of control $a$ are then given by

$$
\begin{aligned}
& F_{e}\left(l^{*} \mid e, a\right)[v-z]+\int_{0}^{l^{*}} F_{e}(l \mid e, a) \mathrm{d} l-1=0 \\
& F_{a}\left(l^{*} \mid e, a\right)[v-z]+\int_{0}^{l^{*}} F_{a}(l \mid e, a) \mathrm{d} l-1=0
\end{aligned}
$$

The optimal values of $e$ and a, defined by (11) and (12), are unique because $F$ is strictly concave. A comparison of (11) with (4) indicates that $W_{e}($.$) is strictly$ positive at the level of care selected by the firm. Similarly, an inspection of (12) and (5) reveals that $W_{a}($.$) is strictly positive at the level of control selected by$ the creditor. Assuming that the second order conditions $W_{e e}()<$.0 and $W_{a a}()<$.0 hold over the relevant rage, Result 1 follows:

Result 1: Suppose that creditors enjoy full priority in bankruptcy. Then under full information, the entrepreneur will exert less than the socially efficient level 
of care. Similarly, the creditor will undertake less than the socially efficient level of control.

\subsubsection{Priority for Tort Claims}

Suppose now that the priority structure was altered to give tort claimants priority. Under this scheme, tort claimants would be paid before creditors. The entrepreneur's expected payoff in this setting is unaltered and continues to be described by (6). The lender's expected payoff is modified, however, and can be written as

$$
\pi=\int_{0}^{l^{*}}(1+R) f(l \mid e, a) \mathrm{d} l+\int_{l^{*}}^{L} \max \{0,[(1+z)-l]\} f(l \mid e, a) \mathrm{d} l-a-\rho
$$

Thus, with probability $F\left(l^{*} \mid e, a\right)$, the firm is solvent, in which creditor receives $(1+R)$. However, over the interval $\left[l^{*}, L\right]$ the firm files for bankruptcy and is liquidated. In that event, the creditor, by virtue of her subordinate position, gets paid only once tort victims have been compensated. Note that the creditor enjoys limited liability in the sense that she cannot lose more than the firm's liquation value $(1+z)$. Let the point where this limited liability binds be given as $l^{0}$ :

$$
l^{0}=1+z .
$$

This implies that in the states of the world in which the firm is bankrupt, there exists a level of damage $l \in\left[l^{*}, L\right]$ such that for $l<l^{0}$ the creditor recoups $(1+z)-l$ while for $l \geq l^{0}$ she gets nothing. The creditor's expected payoff can thus be rewritten as

$$
\pi=\int_{0}^{l^{*}}(1+R) f(l \mid e, a) \mathrm{d} l+\int_{l^{*}}^{l^{0}}\{[(1+z)-l]\} f(l \mid e, a) \mathrm{d} l-a-\rho .
$$

The program of the borrower is

$$
\max _{a, e, R} u=\int_{0}^{l^{*}}\{(1+v)-(1+R)-l\} f(l \mid e, a) \mathrm{d} l-e
$$

subject to the zero economic-profit condition

$$
\begin{aligned}
& F\left(l^{*} \mid e, a\right)(1+R)+\left[F\left(l^{0} \mid e, a\right)-F\left(l^{*} \mid e, a\right)\right][1+z] \\
& -\int_{l^{*}}^{l^{0}} l f(l \mid e, a) \mathrm{d} l-a-\rho=0 .
\end{aligned}
$$

Substituting for $1+R$ in Equation (16) using (17), the entrepreneur's unconstrained optimization problem becomes

$$
\max _{a, e} u F\left(l^{*} \mid e, a\right)(1+v)+\left[F\left(I^{0} \mid e, a\right)-F\left(l^{*} \mid e, a\right)\right][1+z]-\int_{0}^{l^{0}} I f(l \mid e, a) \mathrm{d} l-e-a-\rho .
$$

The ex ante level of care $e$ and the optimal level of creditor control $a$ are given by

$$
\begin{aligned}
& F_{e}\left(l^{*} \mid e, a\right)[v-z]+\int_{0}^{l^{0}} F_{e}(l \mid e, a) \mathrm{d} l-1=0 \\
& F_{a}\left(l^{*} \mid e, a\right)[v-z]+\int_{0}^{l^{0}} F_{a}(l \mid e, a) \mathrm{d} l-1=0
\end{aligned}
$$

Two questions re pertinent: First, how are the optimal levels of care and 
creditor control affected by the elevation of tort claims in this full information setting? Second, how do the levels of care and creditor control in this setting compare to the social optimum? Since $l^{0}>l^{*}$, a comparison of (19) with (11) and (20) with (12) indicate that elevating tort claims unambiguously leads to more care and more creditor control. Indeed, if the lender's claims are subordinated in this way, it may be possible to achieve the social optimum. To see this, note that as the firm's liquidation value $l^{0}=(1+z)$ becomes sufficiently large, that is, as $l^{0} \rightarrow L$, the first-order conditions (19) and (20) coincide with the first-order conditions (4) and (5). Thus, we can state the following:

Result 2. Suppose that there is no asymmetric information. Then, starting from a situation where creditors are accorded full priority, elevating tort claims ahead of creditors unambiguously leads to more care and creditor control. Moreover, if the firm's liquidation value is sufficiently large, then giving absolute priority to tort claims induces the social optimum.

With these preliminaries, out of the way, we now proceed to consider the solution to the borrower's problem under limited information.

\section{Limited Information Solution}

We now characterize the optimal solution on the assumption that both care and creditor control are not observable. The main point here is that, since the two actions cannot be contracted upon, an enforcement problem arises. Hence the optimal contract must be structured to ensure that neither party has an incentive to deviate from the agreed-upon actions.

We assume that the gross interest can be agreed upon by the two parties so a self-enforcing contract with respect to $R$ can be implemented. However, we do not allow for the entrepreneur's level of care $e$ and the creditor's level of control $a$ to be contracted upon. Hence, the contract, through the choice of $R$, must provide incentives for the parties to undertake appropriate actions.

To model this bilateral moral hazard situation, we consider a two-stage game played by the two contractual parties ${ }^{6}$. In the first stage, the parties sign a binding contract with respect to $R$. In the second stage, the players take $R$ as given and choose their actions $e$ and $a$. We examine the solution to this problem under the two alternative bankruptcy priority rules.

\subsection{Creditor Priority}

\subsubsection{Care and Creditor Control Choices}

We begin our analysis at the last stage of the game. Since $a$ and $e$ are chosen noncooperatively, we can analyse the problem by examining the reaction function equilibrium. For any given $R$, the creditor chooses the level of control to maximize it expected payoff with respect to $a$, given her conjecture about the level of $e$. That is, the creditor solves the following problem:

$$
\max _{a} \pi(a ; e, R)=F\left(I^{*} \mid e, a\right)(1+R)+\left[1-F\left(l^{*} \mid e, a\right)\right][1+z]-a-\rho .
$$

${ }^{6}$ For a detailed analysis of double sided moral hazard problems, see, for example, Cooper and Ross [25] [26], Demski and Sappington [27], Kim and Wang [28], and Bhattacharyya and Laffontaine [29]. 
The first order condition reduces to

$$
\pi_{a}=F_{a}\left(I^{*} \mid e, a\right)[R-z]-1=0
$$

Equation (22) indicates that, at the creditor's optimum, the marginal return from control must just be equal to the marginal disutility of control. The second order condition associated with the choice of creditor control is

$$
\pi_{a a}=F_{a a}\left(l^{*} \mid e, a\right)[R-z]<0,
$$

which holds globally by virtue of the fact that $F(l \mid e, a)$ is concave in a. Similarly, for any given $R$, the borrower chooses the level of care to maximize its expected payoff with respect to $e$, given their conjecture about the level of $a$. That is, the borrower solves the following problem:

$$
\max _{e} u(e ; a, R)=\int_{0}^{l^{*}}\{(1+v)-(1+R)-l\} f(l \mid e, a) \mathrm{d} l-e .
$$

The first order condition reduces to

$$
\int_{0}^{l^{*}} F_{e}(l \mid e, a) \mathrm{d} l-1=0
$$

The second order condition associated with the choice of care is

$$
\int_{0}^{l^{*}} F_{e e}(l \mid e, a) \mathrm{d} l<0 .
$$

An important issue to consider is the effects of changes in the interest rate $R$ on the level of care and control in stage 2. From the total differentiation of (22) with respect to $a$ and $R$, we obtain

$$
\frac{\mathrm{d} a}{\mathrm{~d} R}=-\frac{F_{a}\left(l^{*} \mid e, a\right)\left[1-\frac{f_{a}\left(l^{*} \mid e, a\right)}{F_{a}}(R-z)\right]}{F_{a a}\left(l^{*} \mid e, a\right)[R-z]}>0 .
$$

Similarly, total differentiation of (25) with respect to $e$ and $R$ yields

$$
\frac{\mathrm{d} e}{\mathrm{~d} R}=\frac{F_{e}(l \mid e, a)}{\int_{0}^{l^{*}} F_{e e}(l \mid e, a) \mathrm{d} l}<0 .
$$

Thus, an increase in $R$, holding $e$ constant, increases creditor control. There are two effects here that tend to reinforce each other: First, an increase in $R$ increases the creditor's return in those states of world in which the firm is solvent. Second, an increase in $R$, all else being equal, increases the probability of bankruptcy, increasing the range of the states of the world in which the creditor receives a return for control. In contrast, an increase in $R$, holding a constant, reduces the firm's level of care. The reason for this is that an increase in $R$ increases the probability of insolvency, reducing the range of states in which the entrepreneur earns a return from exercising care.

\subsubsection{The Optimal Financial Contract}

Denote the unique equilibrium of the noncooperative game, for given $R$, by $e(R)$ and $a(R)$. The first stage of the game is then to choose $R$, given $e(R)$ 
and $a(R)$. The program of the borrower can be written as

$$
\max _{R} u=\int_{0}^{l^{*}}\{(1+v)-(1+R)-l\} f(l \mid e, a) \mathrm{d} l-e
$$

subject to $(e, a)$ satisfies (22) and (25), and

$$
\pi=F\left(l^{*} \mid e, a\right)(1+R)+\left[1-F\left(l^{*} \mid e, a\right)\right][1+z]-a-\rho=0 .
$$

Constraint (30) shows the lender's zero economic-profit condition. We again simplify the problem by substituting constraints (30) into the objective function. Carrying out this step, an equivalent representation of the borrower's problem becomes:

$$
\begin{aligned}
\max _{R} u(R)= & F\left(l^{*} \mid e(R), a(R)\right)(1+v)+\left[1-F\left(l^{*} \mid e(R), a(R)\right)\right][1+z] \\
& -\int_{0}^{l^{*}} l f(l \mid e(R), a(R)) \mathrm{d} l-e(R)-(R)-\rho .
\end{aligned}
$$

The key feature of the solution to problem (31) is now reported in Proposition 1.

Proposition 1. Under limited information and $A P R$, the necessary condition for the optimal level of care and control satisfies

$$
\begin{aligned}
& \int_{0}^{l^{*}} F_{a}(l \mid e(R), a(R)) \mathrm{d} l \frac{\partial a(R)}{\partial R}+F_{e}\left(l^{*} \mid e(R), a(R)\right)[R-z] \frac{\partial e(R)}{\partial R} \\
& -f\left(l^{*} \mid e(R), a(R)\right)[R-z]=0 .
\end{aligned}
$$

Proof. Partially differentiating Equation (31) with respect to $R$ we obtain

$$
\begin{aligned}
& \left\{F_{a}\left(l^{*} \mid e(R), a(R)\right)[v-z]-1-\int_{0}^{l^{*}} l f_{a}(l \mid e(R), a(R)) \mathrm{d} l\right\} \frac{\partial a(R)}{\partial R} \\
& +\left\{F_{e}\left(l^{*} \mid e(R), a(R)\right)[v-z]-1-\int_{0}^{l^{*}} I f_{a}(l \mid e(R), a(R)) \mathrm{d} l\right\} \frac{\partial e(R)}{\partial R} \\
& -f\left(l^{*} \mid e(R), a(R)\right)[v-z]+l^{*} f\left(l^{*} \mid e(R), a(R)\right)=0 .
\end{aligned}
$$

Making use of the fact that

$$
\int_{0}^{l^{*}} I f_{a}(l \mid e(R), a(R)) \mathrm{d} l=l^{*} F_{a}\left(l^{*} \mid e(R), a(R)\right)-\int_{0}^{l^{*}} F_{a}(l \mid e(R), a(R)) \mathrm{d} l
$$

and $l^{*}=v-R$, Equation(33) reduces to

$$
\begin{aligned}
& \left\{F_{a}\left(l^{*} \mid e^{P}(R), a^{P}(R)\right)[R-z]-1+\int_{0}^{l^{*}} F_{a}\left(l \mid e^{P}(R), a^{P}(R)\right) \mathrm{d} l\right\} \frac{\partial a^{P}(R)}{\partial R} \\
& +\left\{F_{e}\left(l^{*} \mid e^{P}(R), a^{P}(R)\right)[R-z]+\int_{0}^{l^{*}} F_{e}\left(l \mid e^{P}(R), a^{P}(R)\right) \mathrm{d} l-1\right\} \frac{\partial e^{P}(R)}{\partial R} \\
& -f\left(l^{*} \mid e^{P}(R), a^{P}(R)\right)[v-z]+l^{*} f\left(l^{*} \mid e^{P}(R), a^{P}(R)\right) .
\end{aligned}
$$

But

$$
F_{a}\left(l^{*} \mid e, a\right)[R-z]-1=0
$$

and

$$
\int_{0}^{l^{*}} F_{e}(l \mid e, a) \mathrm{d} l-1=0
$$


Hence, Equation (34) simplifies to (32).

\subsection{Priority for Tort Claims}

For any given $R$, the creditor chooses the level of control to maximize it expected payoff with respect to $a$, given her conjecture about the level of $e$. That is, the creditor solves the following problem:

$$
\max _{a} \int_{0}^{l^{*}}(1+R) f(l \mid e, a) \mathrm{d} l+\int_{l^{*}}^{l^{0}}\{[(1+z)-l]\} f(l \mid e, a) \mathrm{d} l-a-\rho .
$$

After integrating by parts and simplifying, Equation (35) can be rewritten as

$$
F\left(l^{*} \mid e, a\right)[v-z]+\int_{l^{*}}^{l^{0}} F(l \mid e, a) \mathrm{d} l-a-\rho .
$$

The first order condition reduces to

$$
\pi_{a}=F_{a}\left(l^{*} \mid e, a\right)[v-z]+\int_{l^{*}}^{l^{0}} F_{a}(l \mid e, a) \mathrm{d} l-1=0
$$

From the total differentiation of (37) with respect to $R$, we obtain

$$
\frac{\mathrm{d} a}{\mathrm{~d} R}=-\frac{F_{a}\left(l^{*} \mid e, a\right)\left[1-\frac{f_{a}\left(l^{*} \mid e, a\right)}{F_{a}}(v-z)\right]}{F_{a a}\left(l^{*} \mid e, a\right)[v-z]+\int_{l^{*}}^{l^{0}} F_{a a}(l \mid e, a) \mathrm{d} l}>0 .
$$

In the first stage, the program of the borrower can be written as

$$
\max _{a, e, R} u=\int_{0}^{l^{*}}\{(1+v)-(1+R)-l\} f(l \mid e, a) \mathrm{d} l-e
$$

subject to subject to $(e, a)$ satisfies (37) and (25), and

$$
\left.\int_{0}^{l^{*}}(1+R) f(l \mid e, a) \mathrm{d} l+\int_{l^{*}}^{l^{0}}[(1+z)-l]\right\} f(l \mid e, a) \mathrm{d} l-a-\rho=0 .
$$

Given the zero economic-profit condition (40), the unconstrained optimization problem becomes

$\max _{R} u F\left(l^{*} \mid e(R), a(R)\right)(1+v)+\left[F\left(l^{0} \mid e(R), a(R)\right)-F\left(l^{*} \mid e(R), a(R)\right)\right][1+z]$

$-\int_{0}^{l^{0}} \operatorname{lf}(l \mid e(R), a(R)) \mathrm{d} l-e-a-\rho$.

The key feature of the solution to problem (41) is reported in Proposition 1. The proof of this proposition is similar to the proof of proposition 1, and is therefore omitted.

Proposition 2. Suppose that tort claimants are granted priority in bankruptcy. Then, under limited information, the necessary condition for the optimal level of care and control satisfies

$$
\begin{aligned}
& \int_{0}^{l^{*}} F_{a}(l \mid e(R), a(R)) \mathrm{d} l \frac{\partial a(R)}{\partial R}+F_{e}\left(l^{*} \mid e(R), a(R)\right)[v-z] \frac{\partial e(R)}{\partial R} \\
& -f\left(l^{*} \mid e(R), a(R)\right)[v-z]=0 .
\end{aligned}
$$

Of immediate interest is how elevating tort claims affects the necessary condition for the optimal levels of $e$ and $a$. The answer is provided by comparing condition (42) with condition (32). To see how, first rewrite condition (32) in the 
following useful form:

$$
\begin{aligned}
& \int_{0}^{l^{*}} F_{a}(l \mid e(R), a(R)) \mathrm{d} l \frac{\partial a(R)}{\partial R}+F_{e}\left(l^{*} \mid e(R), a(R)\right)[v-z] \frac{\partial e(R)}{\partial R} \\
& -f\left(l^{*} \mid e(R), a(R)\right)[v-z] \\
& -F_{e}\left(l^{*} \mid e(R), a(R)\right)[v-R] \frac{\partial e(R)}{\partial R}+f\left(l^{*} \mid e(R), a(R)\right)[v-R]=0 .
\end{aligned}
$$

A comparison of (43) with (36) shows that the effect of elevating tort claims ahead of the lender is represented by the term

$$
\Sigma(R) \equiv-F_{e}\left(l^{*} \mid e(R), a(R)\right)[v-R] \frac{\partial e(R)}{\partial R}+f\left(l^{*} \mid e(R), a(R)\right)[v-R]>0
$$

To analyze the incentive effect of elevating tort claims, notice that, because $\Sigma(R)$ is positive, the first three terms of (43) must sum to a negative value in the entrepreneur's optimum. Since $\partial e(R) / \partial R<0$ and $\partial a(R) / \partial R>0$, the necessary condition for Proposition 2 implies that generally $F_{a}(l \mid e(R), a(R))$ must increase and $F_{e}\left(I^{*} \mid e(R), a(R)\right)$ must decrease relative to the case where the creditor is accorded full priority. That is, there is more creditor control and less care under tort priority compared with the case where the creditor enjoys full priority.

The foregoing result is intuitively appealing. Under APR, the creditor earns $(1+R)$ in the non-bankruptcy state and $(1+z)$ in bankruptcy state. Thus, the marginal net return to control is given by $F_{a}\left(l^{*} \mid e, a\right)[R-z]$. With the elevation of tort claims, the creditor continues to earn $(1+R)$ in the non-bankruptcy state, but must now contend with reduced earnings of $(1+z-l)$ in the states of the world in which there is bankruptcy. The marginal net return to control is in this case given by $F_{a}\left(l^{*} \mid e, a\right)[v-z]+\int_{l^{*}}^{l^{0}} F_{a}(l \mid e, a) \mathrm{d} l$. Thus, elevating tort claims increases the portion of the risk of insolvency borne by the creditor thereby increasing the reward that accrues to the creditor from more intense control. This lessens the creditor's moral hazard problem. More still, because the creditor faces increased risk in bankruptcy, she must demand higher loan interest factors from the borrower in order to keep its expected payoff anchored at zero. The higher interest rate causes the creditor to increase control further. However, the higher loan interest rate has a perverse effect in that it also decreases the net marginal return to care, thereby heightening the moral hazard problem on the part of the borrower. In short, while elevating tort claims lessens the severity of the moral hazard problem on the part of the creditor by increasing the incentive to exercise control, it also heightens the borrower's moral hazard problem. Thus, we can state:

Proposition 3. Starting from a situation where creditors are accorded full priority over tort claimants, elevating tort claims causes a shift towards less care and more creditor control.

\subsection{Efficiency}

It remains to determine how elevating tort claims affects efficiency. Denote by 
$\left(e^{i}, a^{i}\right), i=C, T$ the optimal level of care and control under bankruptcy priority regime $i$, where $C$ refers to the APR regime and $T$ refers to the regime that accords priority to the victim. The expected social welfare under regime $i$ is thus given by

$$
W^{i}(.)=F\left(l^{*} \mid e^{i}, a^{i}\right)[v-z]-l+\int_{0}^{L} F\left(l \mid e^{i}, a^{i}\right) \mathrm{d} l-e^{i}-a^{i}-\rho .
$$

where $e^{i}$ and $a^{i}$ are defined by (22), (25) and (37). From Proposition 3, we know that $e^{C}>e^{T}$ while $a^{C}<a^{T}$. Given that $e$ is decreasing in $R$ while $a$ is decreasing in $R$, Proposition 3 implies that $R^{T}>R^{C}$. Thus, we can determine the impact on social welfare of elevating tort claims by examining the sign of the derivative $\frac{\mathrm{d} W(.)}{\mathrm{d} R}$. Differentiating the social welfare function with respect to $R$, we obtain:

$$
\begin{aligned}
\frac{\mathrm{d} W(.)}{\mathrm{d} R}= & {\left[F_{e}\left(l^{*} \mid e^{i}, a^{i}\right)[v-z]+\int_{0}^{L} F_{e}\left(l \mid e^{i}, a^{i}\right) \mathrm{d} l-1\right] \frac{\mathrm{d} e}{\mathrm{~d} R} } \\
& +\left[F_{a}\left(l^{*} \mid e^{i}, a^{i}\right)[v-z]+\int_{0}^{L} F_{a}\left(l \mid e^{i}, a^{i}\right) \mathrm{d} l-1\right] \frac{\mathrm{d} e}{\mathrm{~d} R} .
\end{aligned}
$$

Note that the terms in the square brackets are all positive by virtue of the fact that $e^{i}<e^{*}$ and $a^{i}<a^{*}$ Since the first term in Equation (45) is negative, while the second term is positive, the impact on social welfare of deviating from APR in favour of tort victims is ambiguous. This observation leads to the following:

Proposition 4. Starting from a situation where creditors are accorded full priority over tort claimants, elevating tort claims has an ambiguous impact on expected social welfare.

Intuitively, elevating tort claims directly reduces the severity of the moral hazard problem on the part of the creditor. Indirectly, it also leads to an increase in the rate of interest, which further makes the creditor's moral hazard problem less intense. Together, these two effect tend to increase both control and the expected social welfare. This effect is represented by the second term in Equation (45). However, raising the rate of interest tends to lower the level of care because the entrepreneur becomes a residual claimant over a smaller range of states of the world. This decrease in the level of care, which is represented by the first term in Equation (45), is a move in the wrong direction since it tends to decrease expected social welfare.

\section{Discussion and Conclusions}

Our key results are found in propositions 3 and 4, which demonstrate that the effect on ex ante incentives and social welfare of deviating from absolute priority, that is, the effect of elevating the priority of tort claims ahead of creditors, is qualitatively ambiguous. The ambiguity stems from the recognition that the information asymmetry (i.e., the moral hazard problem) that exists between lenders and borrowers may be more than a one-sided phenomenon.

The model in this paper is that of a double sided moral hazard, where the creditor exploits its contractual relationship to influence the performance of the 
borrower. This assumption sets our paper apart from studies that focus on the "special" role of financial intermediaries as delegated monitors. In these studies, creditor intervention is presumed to curtail the moral hazard problem [18]-[23]. In the current model, by contrast, the creditor's intervention is not aimed at reducing the severity of managerial moral hazard. Rather, it allows the creditor to have a direct influence over the firm's performance-much in the same way that shareholders or board of directors control the firm's direction.

In the context of tort deterrence, the principal objective of deviating from APR is that such deviation exposes creditors to tort liability. That is, APR deviations should induce creditors to intervene more intensely in the affairs of the firm. In the current model, such exposure should give the creditor the incentive to increase $a$. The key instrument employed by the creditor to motivate itself is the rate of interest. Elevating tort claims ahead of secured creditors essentially increases the creditors' share of tort liability, which increases the creditor's incentive to increase its effort a. Put somewhat differently, subordinating the secured creditor's claim to that of the victim reduces the severity of the moral hazard problem on the part of the creditor, which is a move in the right direction. The creditor's induced desire to exert itself more intensely shows itself in the form an increase in interest rate. However, the higher loan interest rate has a perverse effect in that it also decreases the net marginal return to care, thereby heightening the moral hazard problem on the part of the borrower. In short, while elevating tort claims lessens the severity of the moral hazard problem on the part of the lender by increasing the incentive to monitor, it also heightens the borrower's moral hazard problem. The overall effect on expected tort liability and social welfare of deviating from APR is, thus, ambiguous.

The foregoing argument highlights a potential drawback of deviating from APR: elevating the rights of tort claimants boosts creditor intervention, but also reduces entrepreneurial effort. In other words, tort priority leads to a substitution of creditor intervention for entrepreneurial effort. To see why this kind of substitution is potentially inefficient, assume a situation where the entrepreneur has a comparative advantage, viz-a-vis the creditor, in running the firm. In this case, it is straightforward that as a result of deviating from APR, the benefits from more creditor intervention will be more than offset by the loss from less entrepreneurial effort and elevating the rights of tort claimants will be unambiguously inefficient.

That deviating from APR can be inefficient is not a novel insight. Bebchuk [14] finds that such deviation exacerbates moral hazard problems by strengthening the incentive of equity holders and managers to favour risky projects/investment. In their model, APR deviations aggravate distortions in favour of risky projects by increasing what equity holders and managers receive in bad times and thus the fraction of the downside risk borne by debt holders. Longhofer [11] shows that APR violations exacerbate credit rationing problems by reducing the payment lenders receive in default states. These two studies contrast with ours where entrepreneurial effort is distorted simply because the creditor must be 
motivated more intensely.

Our model admits the distinct possibility that APR deviation can be economically efficient. This outcome is more likely if the moral hazard problem on the part of the creditor is more intense than the moral hazard problem on the part of the entrepreneur. Like in his paper, the efficiency of APR violation has been highlighted in a number of existing studies. Using a model in which firms can use funds owed to a tax authority to pay trade creditors before filing for reorganization, Fisher, Martel and Gaviousca [4] show that raising priority for the tax authority can improve economic welfare by reducing the incentive for firms to engage in claims substitution. In Berkovitch, Israel, and Zender [5] [6] deviation from AP increases the entrepreneur's incentive to exert effort by protecting the sunk investment. Heinkel and Zechner [7], Kalay and Zender [8], and Berkovitch and Israel [9] [10] demonstrate that deviations from APR improve the bankruptcy outcome as they facilitate the transfer of information between privately informed managers and their less informed creditors.

In deriving our results, we made several simplifying assumptions from a much more complicated situation. So it is important that the qualitative predictions of the model be interpreted with caution. First, to keep things particularly simple, we have abstracted from modelling risk preferences presuming, instead, that all parties are risk neutral. A natural extension might admitalternative specification of risk preferences. Second, we proved our findings in a model in which the firm is financed with a fixed amount of debt and only one type of financial instrument. While the presumption of fixed borrowing served a pedagogical purpose, it might not be an accurate description of the real world. In practice, a borrower may have latitude over the amount of borrowing or its choice of financial instrument. Thus, it may be appropriate to determine whether the qualitative conclusions that arise in the fixed-debt setting persist more generally. Third, we assumed that all borrowers have the same level of internal resources and in this way precluded the possibility of credit rationing. A meaningful extension might allow for heterogeneity among firms in terms of their initial wealth endowment and hence their external resource requirement. Finally, the framework adopted in this paper could be used to analyze other remedies to suboptimal tort deterrence. Such remedies include extended liability, mandatory insurance and bonding [30] [31].

\section{References}

[1] Meckling, W.H. (1977) Financial Markets, Default, and Bankruptcy: The Role of the State. Law \& Contemporay Problems, 13, 30-31.

[2] Couwenberg, O. and Lubben, S.J. (2013) Solving Creditor Problems in the Twilight Zone: Superfluous Law and Inadequate Private Solutions. International Review of Law and Economics, 34, 61-76.

[3] Elson, C.M. and Rasmussen, R.K. (2003) Switching Priorities: Elevating the Status of Tort Claims in Bankruptcy in Pursuit of Optimal Deterrence. Harvard Law Review, 116, 2541-2564. https://doi.org/10.2307/1342770

[4] Fisher, T.C.G., Martel, J. and Gavious, I. (2016) Tax Claims, Government Priority, 
Absolute Priority and the Resolution of Financial Distress. International Review of Law and Economics, 48, 50-58.

[5] Berkovitch, E., Israel, R. and Zender, J.F. (1997) An Optimal Bankruptcy Law and Firm Specific Investments. European Economic Review, 41, 487-497.

[6] Berkovitch, E., Israel, R. and Zender, J.F. (1998) The Design of Bankruptcy Law: A Case for Management Bias in Bankruptcy Reorganizations. Journal of Financial and Quantitative Analysis, 33, 441-464.

[7] Heinkel, R. and Zechner, J. (1993) Financial Distress and Optimal Capital Structure Adjustments. Journal of Economics \& Management Strategy, 2, 531-565.

[8] Kalay, A. and Zender, J.F. (1997) Bankruptcy, Warrants, and State-Contingent Changes in the Ownership of Control. Journal of Financial Intermediation, 6, 347379.

[9] Berkovitch, E. and Israel, R. (1998) The Bankruptcy Decision and Debt Contract Renegotiations. European Finance Review, 2, 1-27.

[10] Berkovitch, E. and Israel, R. (1999) Optimal Bankruptcy Law across Different Economic Systems. The Review of Financial Studies, 12, 347-377.

[11] Longhofer, S.D. (1997) Absolute Priority Rule Violations, Credit Rationing, and Efficiency. Journal of Financial Intermediation, 6, 249-267.

[12] Adler, B.E. (1992) Bankruptcy and Risk Allocation. Cornell Law Review, 77, 439489.

[13] Schwartz, A. (1997) Contracting about Bankruptcy. Journal of Law, Economics, \& Organization, 13, 127-146. https://doi.org/10.1093/oxfordjournals.jleo.a023376

[14] Bebchuk, L.A. (2002) Ex Ante Costs of Violating Absolute Priority in Bankruptcy. The Journal of Finance, 57, 445-460. https://doi.org/10.1111/1540-6261.00427

[15] Nini, G., Smith, D.C. and Sufi, A. (2012) Creditor Control Rights, Corporate Governance, and Firm Value. Review of Financial Studies, 25, 1713-1761. https://doi.org/10.1093/rfs/hhs007

[16] Shleifer, A. and Vishny, R. (1997) A Survey of Corporate Governance. Journal of Finance, 52, 737-783. https://doi.org/10.1111/j.1540-6261.1997.tb04820.x

[17] Baird, D. and Rasmussen, R. (2006) Private Debt and the Missing Lever of Corporate Governance. University of Pennsylvania Law Review, 154, 1209-1251. https://doi.org/10.2307/40041322

[18] Diamond, D. (1984) Financial Intermediation and Delegated Monitoring. Review of Economic Studies, 51, 393-414. https://doi.org/10.2307/2297430

[19] Jensen, M.C. (1986) Agency Costs of Free Cash Flow, Corporate Finance, and Takeovers. The American Economic Review, 76, 323-329.

[20] Diamond, D.W. (1991) Monitoring and Reputation: The Choice between Bank Loans and Directly Placed Debt. Journal of Political Economy, 99, 689-721. https://doi.org/10.1086/261775

[21] Rajan, R.G. (1992) Insiders and Outsiders: The Choice between Informed and Arm's-Length Debt. The Journal of Finance, 47, 1367-1400. https://doi.org/10.1111/j.1540-6261.1992.tb04662.x

[22] Sharpe, S. (1990) Asymmetric Information, Bank Lending, and Implicit Contracts: A Stylized Model of Customer Relationships. The Journal of Finance, 45, 10691087.

[23] Besanko, D. and Kanatas, G. (1993) Credit Market Equilibrium with Bank Monitoring and Moral Hazard. Review of Financial Studies, 6, 213-232.

https://doi.org/10.1093/rfs/6.1.213 
[24] Banerji, S., Chane, A.H. and Mazumdar, S.C. (2002) Universal Banking under Bilateral Information Asymmetry. Journal of Financial Services Research, 22, 169-187.

[25] Cooper, R., and Ross, T.W. (1988) An Intertemporal Model of Warranties. Canadian Journal of Economics, 21, 72-86. https://doi.org/10.2307/135211

[26] Cooper, R. and Ross, T.W. (1985) Product Warranties and Double Moral Hazard. RAND Journal of Economics, 16, 103-113. https://doi.org/10.2307/2555592

[27] Demski, J. and Sappington, D. (1991) Resolving Double Moral Hazard Problems with Buyout Agreements. RAND Journal of Economics, 22, 232-240. https://doi.org/10.2307/2601019

[28] Kim, S.K. and Wang, S. (1998) Linear Contracts and the Double Moral Hazard. Journal of Economic Theory, 82, 342-378.

[29] Bhattacharyya, S. and Laffontaine, F. (1995) Double Sided Moral Hazard and the Nature of Share Contracts. RAND Journal of Economics, 26, 761-781. https://doi.org/10.2307/2556017

[30] Pitchford, R. (1995) How Liable Should a Lender Be? The Case of Judgment-Proof Firms and Environmental Risk. The American Economic Review, 85, 1171-1186.

[31] Hutchinson, E. and van't Veld, K. (2005) Extended Liability for Environmental Accidents: What You See is What You Get. Journal of Environmental Economics and Management, 49, 157-173.

Submit or recommend next manuscript to SCIRP and we will provide best service for you:

Accepting pre-submission inquiries through Email, Facebook, LinkedIn, Twitter, etc. A wide selection of journals (inclusive of 9 subjects, more than 200 journals)

Providing 24-hour high-quality service

User-friendly online submission system

Fair and swift peer-review system

Efficient typesetting and proofreading procedure

Display of the result of downloads and visits, as well as the number of cited articles

Maximum dissemination of your research work

Submit your manuscript at: http://papersubmission.scirp.org/

Or contact tel@scirp.org 